\title{
Feeding and Reward Are Differentially Induced by Activating GABAergic Lateral Hypothalamic Projections to VTA
}

\author{
M. Flavia Barbano, Hui-Ling Wang, Marisela Morales, and Roy A. Wise \\ Integrative Neuroscience Research Branch, National Institute on Drug Abuse, Baltimore, Maryland 21224
}

Electrical stimulation of the lateral hypothalamus (LH) has two motivational effects: long trains of stimulation induce drive-like effects such as eating, and short trains are rewarding. It has not been clear whether a single set of activated fibers subserves the two effects. Previous optogenetic stimulation studies have confirmed that reinforcement and induction of feeding can each be induced by selective stimulation of GABAergic fibers originating in the bed nucleus of the LH and projecting to the ventral tegmental area (VTA). In the present study we determined the optimal stimulation parameters for each of the two optogenetically induced effects in food-sated mice. Stimulation-induced eating was strongest with $5 \mathrm{~Hz}$ and progressively weaker with 10 and $20 \mathrm{~Hz}$. Stimulation-induced reward was strongest with $40 \mathrm{~Hz}$ and progressively weaker with lower or higher frequencies. Mean preferred duration for continuous $40 \mathrm{~Hz}$ stimulation was $61.6 \mathrm{~s}$ in a "real-time" place preference task; mean preferred duration for $5 \mathrm{~Hz}$ stimulation was $45.6 \mathrm{~s}$. The differential effects of high- and low-frequency stimulation of this pathway seem most likely to be due to differential effects on downstream targets.

Key words: feeding; GABA; lateral hypothalamus; optogenetics; reward; ventral tegmental area

\section{Significance Statement}

Our study reports that the eating and the reward induced by optogenetic stimulation of a previously identified GABAergic projection from the lateral hypothalamus to the ventral tegmental area are differentially affected by low- and high-frequency stimulation, respectively. This suggests a way that stimulation of the same pathway can have very different motivational effects on behavior, inducing a drive state (usually thought to be aversive) under one condition and inducing the rewarding state under another. This offers an insight into what has been called the "drive-reward paradox": why would an animal work for stimulation that established an apparent drive state?

\section{Introduction}

The lateral hypothalamus (LH) has long been implicated by lesion and electrical stimulation studies in feeding and reward (Anand and Brobeck, 1951; Olds, 1956; Margules and Olds, 1962; Hoebel, 1969). Although the cells of the LH were traditionally assumed to integrate feeding-related signals (Saper et al., 2002; Berthoud and Münzberg, 2011), it was not clear whether LH cells of origin or medial forebrain bundle fibers of passage were responsible for the disruptions of feeding and reward caused by

Received 0ct. 16, 2015; revised Jan. 14, 2016; accepted Feb. 2, 2016.

Author contributions: M.F.B., H.-L.W., M.M., and R.A.W. designed research; M.F.B. and H.-L.W. performed research; M.M. contributed unpublished reagents/analytic tools; M.F.B., H.-L.W., M.M., and R.A.W. analyzed data; M.F.B., M.M., and R.A.W. wrote the paper.

This work was supported by the Intramural Research Program of the National Institute on Drug Abuse. We thank the NIDA Optogenetic and Transgenic Technology Core for providing the viral vectors used in this study.

The authors declare no competing financial interests.

Correspondence should be addressed to Dr. Roy A. Wise, Integrative Neuroscience Research Branch, National Institute on Drug Abuse, 251 Bayview Boulevard, Baltimore, MD 21224. E-mail: rwise@intra.nida.nih.gov.

M. F. Barbano's present address: Department of Psychological and Brain Sciences, Johns Hopkins University, 3400 North Charles Street, Baltimore, Maryland 21218

DOI:10.1523/JNEUROSCI.3799-15.2016

Copyright $\odot 2016$ the authors $\quad 0270-6474 / 16 / 362975-11 \$ 15.00 / 0$ lateral hypothalamic lesions (Ungerstedt, 1971; Stricker and Zigmond, 1974) or the induction of feeding and reward by electrical stimulation (Ranck, 1975; Bielajew et al., 2000). Previous optogenetic studies have now confirmed that activation of GABAergic projections to the VTA from LH cells of origin is sufficient to induce feeding (Jennings et al., 2015; Nieh et al., 2015), food seeking (Jennings et al., 2015; Nieh et al., 2015), and reward (Jennings et al., 2015).

It remains unclear whether the two stimulation effects-a drive-like effect with many of the properties of hunger (Wise, 1974) and a reinforcing effect that can establish (i) instrumental response habits (Olds, 1956) and (ii) preference for places where the stimulation has been experienced in the past (Ettenberg and Duvauchelle, 1988)_are responses to activation of the same GABAergic fibers. It seems paradoxical that sated rats should work for stimulation that induces hunger-like state (Wise, 2013). However, electrical stimulation studies indicate that stimulation in the ventral tegmental area and in the lateral hypothalamus can induce both feeding and reward. Moreover, paired-pulse stimulation studies confirm that the reward and feeding involve fibers that connect the two regions (but do not necessarily originate or 
terminate in either of them) and have similar refractory periods, conduction velocities, and anatomical alignment within the medial forebrain bundle (Shizgal et al., 1980; Bielajew and Shizgal, 1982; Gratton and Wise, 1988a,b). The two responses to lateral hypothalamic stimulation have thus never been dissociated, and their common characteristics have been taken to suggest (but do not confirm) that the same fiber population is involved in both effects. This suggestion fits with the optogenetic finding that each effect can be induced by $20 \mathrm{~Hz}$ activation of GABAergic lateral hypothalamic cells (Jennings et al., 2015) that project to the VTA (Nieh et al., 2015).

In the present study, we further characterize the feeding and reward responses induced by optogenetic activation of the GABAergic $\mathrm{LH} \rightarrow$ VTA pathway. We determined latency and amount of feeding, willingness to work for short trains of stimulation, preferred stimulation duration, and preference for a stimulation-associated location in the test apparatus (conditioned place preference) across a range of stimulation frequencies and determined that the rewarding and feeding effects can be differentiated by the different optimal stimulation parameters for the two effects.

\section{Materials and Methods}

Animals

A total of 21 male VGAT-IRES::Cre mice (Slc32a1tm2(cre)Lowl/J, in a C57BL/6J background from The Jackson Laboratories) were used in these studies. Groups of two to five mice (weighing 20-30 g at the start of experiments) were housed in an animal vivarium maintained on a direct $12 \mathrm{~h} \mathrm{light/dark} \mathrm{cycle} \mathrm{(lights} \mathrm{on} \mathrm{at} \mathrm{7:00} \mathrm{A.M.)} \mathrm{and} \mathrm{at} \mathrm{a} \mathrm{constant} \mathrm{tempera-}$ ture of $23^{\circ} \mathrm{C}$. They were kept undisturbed at least 1 week before the start of any experimental procedure and were handled and weighed daily to minimize handling stress during experiments. Food and water were provided ad libitum except during experimental sessions. Animal care and use were in accordance with institutional and international standards (National Research Council, 2011) and were approved by the National Institute on Drug Abuse Animal Care and Use Committee. All experiments were performed during the light phase of the diurnal cycle.

\section{Drugs and food}

Except for saclofen (Tocris Bioscience), the drugs were purchased from Sigma Aldrich. Saclofen and picrotoxin were dissolved in artificial CSF (ACSF; $124 \mathrm{~mm} \mathrm{NaCl}, 5 \mathrm{~mm} \mathrm{KCl}, 1.25 \mathrm{~mm} \mathrm{NaH}_{2} \mathrm{PO}_{4}, 2$ mм MgSO 410 $\mathrm{mm}$ glucose, $\mathrm{pH}$ 7.4). The animals were tested with and after free access to their normal laboratory chow (2018 Teklad Global 18\% protein rodent diet, Harlan; $18.6 \%$ protein, $44.2 \%$ carbohydrate, $6.2 \%$ fat, with a caloric content of $3.1 \mathrm{kcal} / \mathrm{g})$.

\section{Surgical and intracerebral infusion procedures}

Each mouse was anesthetized with $1-5 \%$ isofluorane, placed in a stereotaxic frame, and its skull exposed and leveled. Cre-inducible adenoassociated virus (AAV, serotype 1) coding for the light-sensitive protein channelrhodopsin-2 (ChR2) and enhanced yellow fluorescent protein (eYFP) or for eYFP alone under control of the $\mathrm{EF} 1 \alpha$ promoter was used (National Institute on Drug Abuse Intramural Research Program Optogenetics and Transgenic Technology Core). AAV1-EF1 $\alpha$-DIOhChR2(H134R)-eYFP (ChR2 mice) or AAV1-EF1 $\alpha$-DIO-eYFP (eYFP mice) were bilaterally injected into the LH. The stereotaxic coordinates were as follows: anteroposterior (AP), -1.3 ; mediolateral (ML), \pm 1.0 ; dorsoventral (DV), -5.2 . Injections of $300 \mathrm{nl}$ per side were made with a flow rate of $100 \mathrm{nl} / \mathrm{min}$. Infusions were done using an UltraMicroPump with Micro 4 controller, $10 \mu \mathrm{l}$ Nanofil syringes, and 35 gauge needles (WPI). The needle was left in place for additional $3 \mathrm{~min}$ to prevent reflux. At least 8 weeks after viral infusions, each mouse received an intracranial optic fiber and, in some cases, a guide cannula for VTA microinjections. For optical stimulation of the VTA projections from LH (Fig. 1A), mice were implanted with unilateral chronic optic fibers $(200 \mu \mathrm{m}$ diameter; BFL37-200; Thorlabs) directed just dorsal to the right VTA (AP, -3.4; $\mathrm{ML},-0.3 ; \mathrm{DV},-4.3)$. For pharmacological studies, a guide cannula (22 gauge; PlasticsOne) and an optic fiber were each lowered at a $10^{\circ}$ angle toward the right VTA (optic fiber, AP, -3.4 ; $\mathrm{ML},+0.5$; DV, -4.3 ; cannula, AP, $-3.4 ; \mathrm{ML},+1.1 ; \mathrm{DV},-4.4)$. One or two stainless-steel screws and dental acrylic cement were used to anchor the optic fiber and cannula to the skull. A cap and dummy cannula were used to prevent cannula blockade. Animals were given the analgesic meloxicam $(0.2 \mathrm{mg} / \mathrm{kg})$ to prevent postsurgical pain or discomfort and were allowed at least $10 \mathrm{~d}$ of recovery before the beginning of any experimental manipulation. Body weight was measured daily after surgery.

For intracerebral drug infusion, 28 gauge internal cannula injectors (PlasticsOne) were connected to Nanofil syringes through polyethylene tubing. The infusion volume was $200 \mathrm{nl}$ at a flow rate of $100 \mathrm{nl} / \mathrm{min}$. The injector was left in place for an additional $3 \mathrm{~min}$ to allow diffusion and to prevent the possibility of reflux. At the end of each experiment, the mice were anesthetized and perfused with $4 \%$ paraformaldehyde in $0.1 \mathrm{M} \mathrm{PB}$, and coronal sections of $30 \mu \mathrm{m}$ were cut with a cryostat (CM3050 S; Leica) and prepared as reported previously (Qi et al., 2014). Virus injection and optic fiber and cannula placements were verified by immunohistochemistry.

Brain coronal sections for eYFP immunodetection were processed as follows: free-floating coronal sections were incubated for $1 \mathrm{~h}$ in $\mathrm{PB}$ supplemented with $4 \%$ bovine serum albumin and $0.3 \%$ Triton X-100. Sections were then incubated with mouse anti-GFP antibody (1:1000; catalog no. 632381, Clontech Laboratories) overnight at $4^{\circ} \mathrm{C}$. After rinsing three times for 10 min each in $\mathrm{PB}$ and incubation in biotinylated goat anti-mouse antibody (1:200; Vector Laboratories), sections were rinsed with $\mathrm{PB}$ and incubated for $1 \mathrm{~h}$ at room temperature in avidinbiotinylated horseradish peroxidase (1:200; ABC Kit; Vector Laboratories). Sections were rinsed, and the peroxidase reaction was developed with $0.05 \% 3,3^{\prime}$-diaminobenzidine and $0.03 \% \mathrm{H}_{2} \mathrm{O}_{2}$. Sections were mounted on coated slides. Bright-field images were collected with an Olympus MVX10 with a 0.63 objective (Olympus). For double fluorescence immunodetection of eYFP and tyrosine hydroxylase (TH), freefloating coronal sections were incubated with mixtures of primary antibodies, rabbit anti-TH antibody (1:1000; catalog no. AB152; Millipore) plus mouse anti-GFP primary antibody (1:1000; catalog no. 632381; Clontech Laboratories), overnight at $4^{\circ} \mathrm{C}$. After rinsing three times for 10 min each in $\mathrm{PB}$, sections were incubated in a mixture of the corresponding fluorescence secondary antibodies (1:100; Alexa Fluor; Jackson ImmunoResearch) for $2 \mathrm{~h}$ at room temperature. After rinsing, the sections were mounted on slides. Fluorescent images were collected with an Olympus FV1000 Confocal System. Images were taken sequentially with different lasers with $\times 10$ (for low magnification) or $\times 40$ (for high magnification) objectives.

\section{Behavioral studies}

Apparatus. Feeding studies were conducted in acrylic chambers $(34 \times$ $25 \times 19 \mathrm{~cm})$ containing regular bedding. Optical intracranial selfstimulation studies were conducted in sound-attenuated operant chambers (Med Associates) equipped with two operant response wheels, a house light, and a cue light situated above each of the two wheels. Wheel turns were monitored by MedPC software (Med Associates); each quarter-turn of the designated response wheel caused delivery of optical stimulation. Place preference was tested in a three-compartment chamber consisting of two main chambers $(20 \times 18 \times 35 \mathrm{~cm})$ with distinct wall patterns and a connecting chamber $(20 \times 10 \times 35 \mathrm{~cm})$. For both feeding and place preference studies, the position of the animal was monitored via camera with a video tracking software (AnyMaze, Stoelting). Fiber optic cables were attached via FC/PC connector to $473 \mathrm{~nm}$ lasers (OEM/Opto Engine) for photostimulation.

Feeding studies. ChR2 and eYFP mice were habituated to the testing environment for three days before any experimental manipulation. On a given test day, each mouse was connected to a fiber optic cable and was placed in a chamber with a preweighed amount of food scattered on the floor. Each session lasted $10 \mathrm{~min}$ and was divided into $1060 \mathrm{~s}$ trials. During odd-numbered trials, the laser stimulation remained off. During even-numbered trials, continuous laser stimulation was given in $10 \mathrm{~ms}$ pulses with laser intensity at the end of the fiber optics cable adjusted to 8 $\mathrm{mW}$. Stimulation-induced feeding was assessed at four stimulation fre- 
A

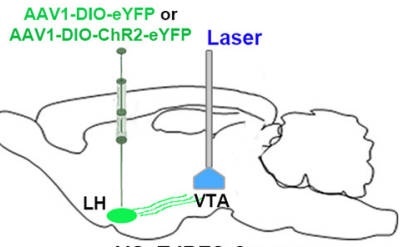

B

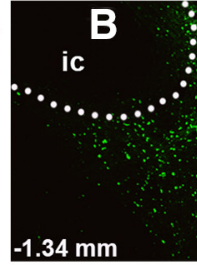

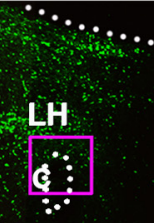

$E$

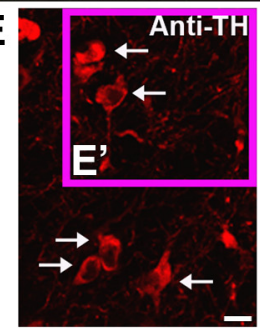

C

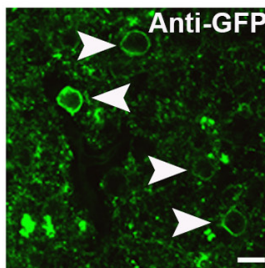

D

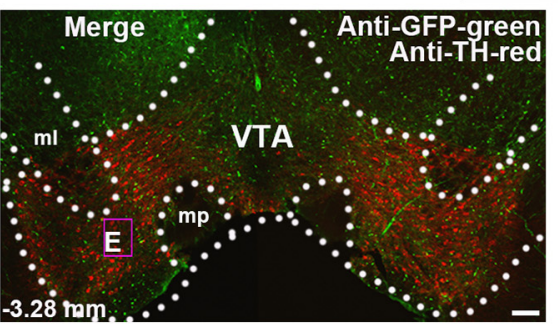

F

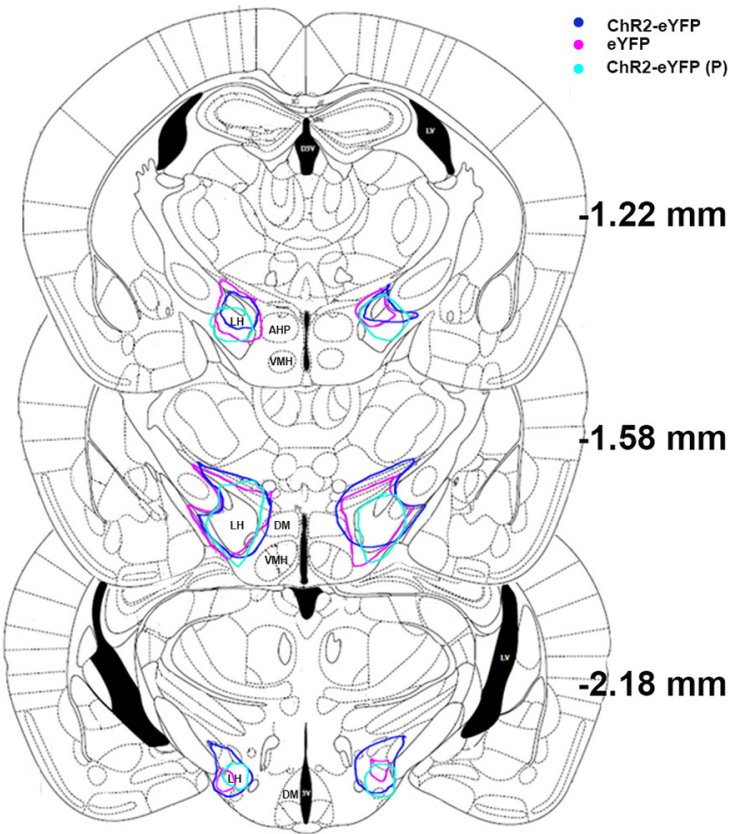

G

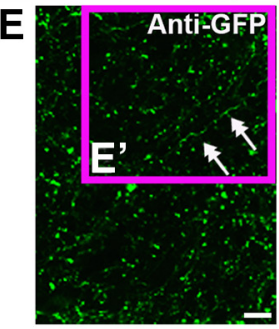

E.
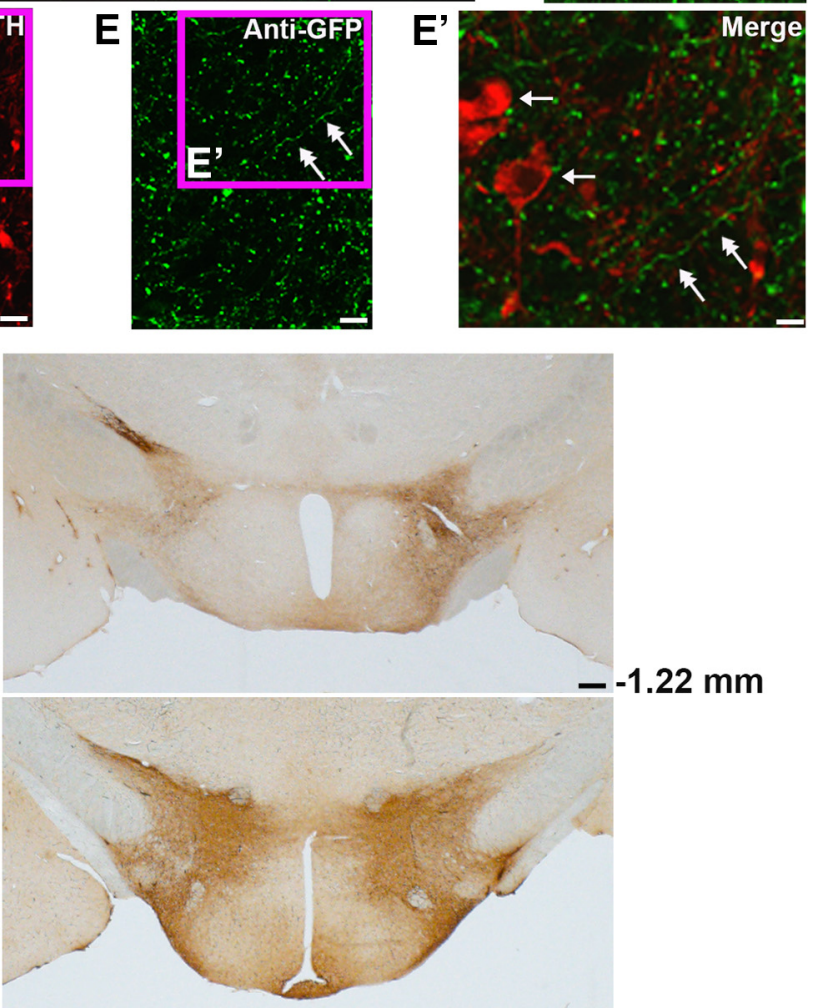

$--1.58 \mathrm{~mm}$

$--2.30 \mathrm{~mm}$

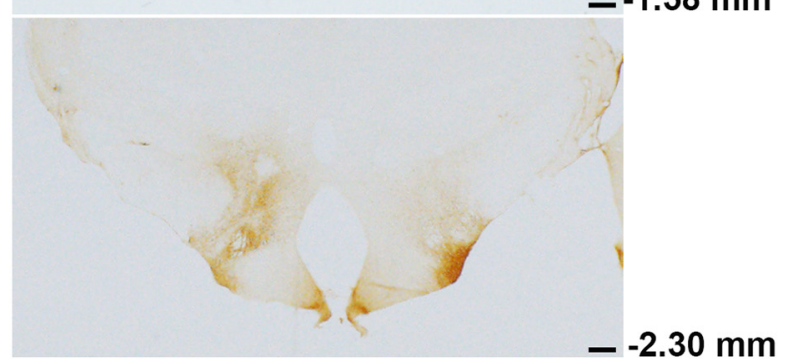

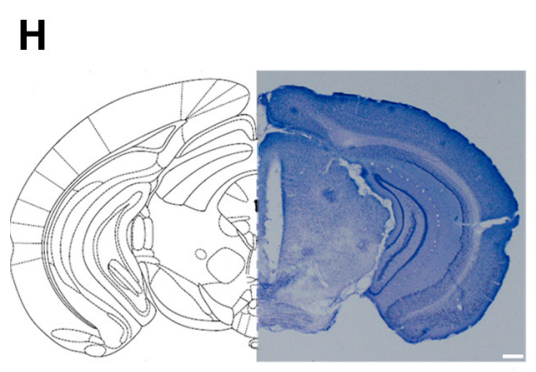

$-3.64 \mathrm{~mm}$

I

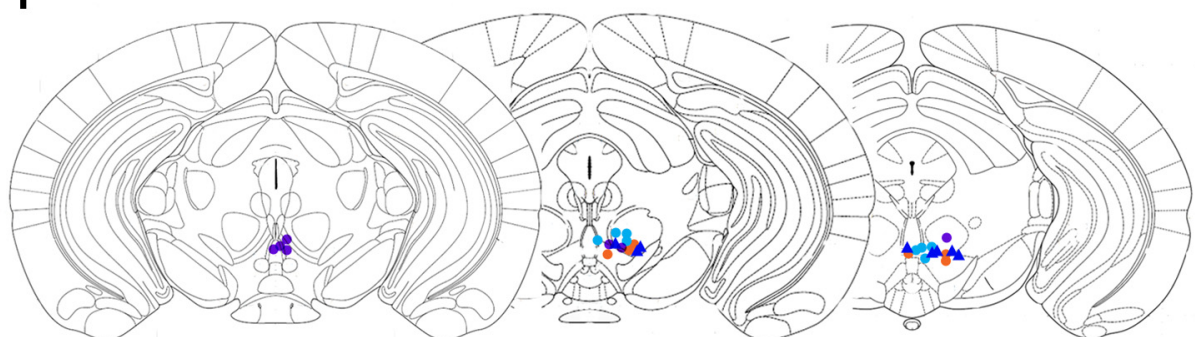

$-3.16 \mathrm{~mm}$

Figure 1. Location of viral injection sites in the LH and optical probe and cannula placements within the VTA.A, The ChR2-carrying vector was injected into the lateral hypothalamus, and the optic fiber was placed over the VTA. LH neurons from VGAT-IRES::Cre mice were bilaterally infected by infusions of either AAV1-DI0-eYFP or AAV1-DI0-ChR2-eYFP viruses. After 8 weeks, an optic fiber (plus a cannula in some experiments) was surgically implanted, aimed at the VTA. $\boldsymbol{B}$, Representative image of a virus injection site within the LH showing the bilateral expression of (hR2-eYFP (green). The location of the fornix (f) is indicated by a dotted white oval, and the distance posterior to bregma is indicated in millimeters. $\boldsymbol{C}$, Area delineated by the pink box in $\boldsymbol{B}$ is shown at a higher magnification. The cell bodies of the infected GABAergic neurons are indicated by white arrowheads. $\boldsymbol{D}$, Expression of both ChR2-eYFP (green) and TH (red) in the VTA shown by immunofluorescence microscopy. The distance from bregma is indicated. $\boldsymbol{E}$, Area delineated by the pink box in $\boldsymbol{D}$ is shown at higher magnification. The cell bodies of dopaminergic neurons (red) are indicated by single arrows. The fibers of GABAergic neurons expressing ChR2-eYFP (green) are indicated by double arrows. $\boldsymbol{E}^{\prime}$, Area delineated by the pink box $\boldsymbol{E}$ is shown at higher magnification. Dopaminergic neurons (red, single arrows) and GABAergic axon terminals (green, double arrows) are indicated. $\boldsymbol{F}$, Extension of viral infusions within the LH of VGAT-IRES::Cre mice, (Figure legend continues.) 
Table 1. Mean amounts of food eaten (in grams) and latency to start eating (in seconds) as well as total and reinforced wheel turns observed during the $3 \mathrm{~d}$ training period previous to the pharmacological experiments conducted on the ChR2 mice for the feeding and optical self-stimulation studies

\begin{tabular}{|c|c|c|c|c|c|c|}
\hline \multirow[b]{2}{*}{ Training } & \multirow[b]{2}{*}{ Amount eaten $(\mathrm{g})$} & \multicolumn{2}{|c|}{ Latency to eat (s) } & \multicolumn{2}{|l|}{ Total wheel turns } & \multirow[b]{2}{*}{ Reinforced wheel turns } \\
\hline & & No light & Light & Active & Inactive & \\
\hline Day 1 & $0.24 \pm 0.06$ & $57.94 \pm 1.54$ & $32.89 \pm 7.79$ & $693.48 \pm 125.95$ & $32.57 \pm 5.45$ & $112.81 \pm 9.70$ \\
\hline Day 2 & $0.31 \pm 0.06$ & $60 \pm 0$ & $25.11 \pm 5.75$ & $1148.88 \pm 106.30$ & $54.19 \pm 22.99$ & $143.38 \pm 11.13$ \\
\hline Day 3 & $0.32 \pm 0.06$ & $60 \pm 0$ & $26.77 \pm 6.95$ & $1086.86 \pm 142.13$ & $40.52 \pm 9.87$ & $143.52 \pm 15.11$ \\
\hline
\end{tabular}

The statistical analyses for each variable are as follows: amount eaten, main effect of days, $F_{(2,12)}=2.61, p=0.11$, n.s.; latency to eat, $\chi^{2}=30.56, p<0.001$, no significant difference between the latencies to eat observed during the no light trials during the 3 training days, as well as no differences between the latencies to eat observed during the light trials during the 3 training days; total wheel turns, main effect of days, $F_{(2,12)}=4.88, p<0.05$; main effect of wheel, $F_{(1,6)}=174.15, p<0.001$; days by wheel interaction, $F_{(2,12)}=3.74, p=0.06$, n.s.; reinforced wheel turns, main effect of days, $F_{(2,12)}=3.22, p=0.08$, n.s.

quencies-2.5, 5, 10, and $20 \mathrm{~Hz}$ - on separate days and in balanced sequence. Latency to start eating and amount eaten were recorded for each trial. On a subsequent day, seven ChR2 mice were tested with cardboard and food each scattered on the floor; latency to pick up and bite cardboard or food and weights of the cardboard and food before and after testing were recorded. Stimulation parameters for this test and all others, unless otherwise noted, were $10 \mathrm{~ms}$ pulses at $5 \mathrm{~Hz}$ and $8 \mathrm{~mW}$ laser intensity.

For pharmacological experiments, ChR2 mice were habituated to the testing environment and given $3 \mathrm{~d}$ of stimulation testing at $5 \mathrm{~Hz}$ to obtain a food intake baseline (Table 1). On the fourth day, a mix of saclofen (500 $\mu \mathrm{M})$ and picrotoxin $(100 \mu \mathrm{M})$ was infused into the VTA before similar testing. Three minutes after infusion, the animals were again tested with $5 \mathrm{~Hz}$ photostimulation. Distance traveled and average speed were also measured to assess motor performance. Three days after intra-VTA infusion of the GABA antagonists, the animals were retested following VTA infusions of ACSF.

Optical intracranial self-stimulation studies. ChR2 and eYFP mice were connected to the fiber optic cable and laser and were placed in operant chambers equipped with two response wheels (left and right) for daily 30-min self-stimulation testing. Each session began with illumination of the house light, which remained on for the entire session. Quarter-turns of one wheel ("active" wheel) activated a cue light above the wheel and caused a $2 \mathrm{~s}$ train of $20 \mathrm{~Hz}$ photostimulation $(8 \mathrm{~mW}, 10 \mathrm{~ms})$ followed by a $0.5 \mathrm{~s}$ "time-out" during which stimulation was not available. The cue light remained illuminated until the end of the time-out. Responses on the other ("inactive") wheel were not rewarded. During the first $5 \mathrm{~d}$ of training, the right wheel was designated as the active wheel; during the next $5 \mathrm{~d}$ the left wheel was the active wheel. Total wheel turns in the active and inactive wheels as well as reinforced wheel turns were recorded.

After $10 \mathrm{~d}$ of training at $20 \mathrm{~Hz}$, the animals were tested with a range of pulse widths and pulse frequencies. On each test day, the mice were given eight 10 min trials with stimulation at one of four pulse widths $(1.25,2.5$, 5 , and $10 \mathrm{~ms}$ ). In each of the eight daily trials, the mice were tested at one of eight frequencies $(1.25,2.5,5,10,20,40,80$ and $160 \mathrm{~Hz})$. The order of

$\leftarrow$

(Figure legend continued.) arranged rostrocaudally. The blue outlines correspond to a mouse injected with AAV1-DI0-ChR2-eYFP (experimental group, ChR2-eYFP), the pink outlines correspond to a mouse injected with AAV1-DI0-eYFP (control group, eYFP), and the light blue outlines correspond to a mouse injected with AAV1-DI0-ChR2-eYFP (experimental group used in pharmacological studies, ChR2-eYFP (P)). The distance from bregma is indicated. G, Representative coronal sections of VGAT-IRES::Cre mice showing the rostrocaudal extension of viral infusions. The images of the coronal sections were taken at low magnification under bright-field microscopy and show GFP immunoreactivity (dark brown label) in the LH. The distance from bregma is indicated. $\boldsymbol{H}$, Representative coronal section image and atlas schema of an optical fiber placement within the VTA. The distance from bregma is indicated. I, Placements of optic fibers and cannulae for all the mice in the study. Purple circles show optic probe tips for mice injected with AAV1-DI0-ChR2-eYFP (experimental group), orange circles show optic probe tips for mice injected with AAV1-DI0-eYFP (control group), light blue circles show optic probe tips for mice injected with AAV1-DI0-ChR2-eYFP (experimental group used in pharmacological studies), and blue triangles show cannula tips for mice injected with AAV1-DI0-ChR2-eYFP (experimental group used in pharmacological studies). The distance from bregma is indicated. 3V, Third ventricle; AHP, anterior hypothalamus; DM, dorsomedial hypothalamus; ic, internal capsule; $\mathrm{ml}$, medial lemniscus; $\mathrm{mp}$, mammillary peduncle; $\mathrm{VMH}$, ventromedial hypothalamus. Scale bars: $\boldsymbol{B}, 96 \mu \mathrm{m} ; \boldsymbol{C}, 21.6 \mu \mathrm{m} ; \boldsymbol{D}, 60 \mu \mathrm{m} ; \boldsymbol{E}, 17 \mu \mathrm{m} ; \boldsymbol{E}^{\prime}, 9.5 \mu \mathrm{m} ; \boldsymbol{G}, 120 \mu \mathrm{m} ; \boldsymbol{I}, 112.5 \mu \mathrm{m}$. pulse widths was balanced across days; pulse frequencies were tested in ascending order for half the mice and descending order for the others.

For pharmacological experiments, ChR2 mice were given three daily 10 min baseline training sessions (Table 1 ) with stimulation at $40 \mathrm{~Hz}(8$ $\mathrm{mW}, 10 \mathrm{~ms})$. On the fourth day, a mix of saclofen $(500 \mu \mathrm{M})$ and picrotoxin $(100 \mu \mathrm{M})$ was infused into the VTA. Three minutes after infusion, the animals were placed in the operant boxes and retested. Three days after intra-VTA infusion of the GABA antagonists, the animals were retested following VTA infusion of ACSF.

Preferred duration and place conditioning studies. Place preference experiments were divided into three phases: pretest, preferred duration, and conditioned preference phases. During the $10 \mathrm{~min}$ pretest phase, ChR2 and eYFP mice were connected to the fiber optic cable and laser, placed in the connecting chamber, and allowed to freely explore the entire apparatus. Time spent in each compartment was measured. In the preferred duration phase, the mice were allowed, in 30 min tests on 4 consecutive days, to instrumentally initiate or terminate continuous trains of stimulation by entering or exiting one of the end compartments of the apparatus. Independent groups were tested with stimulation at 5 or $40 \mathrm{~Hz}$; times spent in each compartment were recorded. On the following day, the animals were tested in the absence of stimulation to determine if they had developed a conditioned preference for any of the three chambers.

\section{Statistical analyses}

Results are presented as mean \pm SEM. Latencies to start eating were compared to arbitrary cutoff scores using nonparametric methods due to a lack of variance for the cutoff data. Friedman ANOVA was used to detect any intertrial differences in a given group, Wilcoxon paired test was used to detect intertrial variations, and the Mann-Whitney $U$ test was performed to detect between-groups differences. The remaining data were analyzed using parametric methods.

Behavioral data were analyzed using a Student's $t$ test in the case where two variables were to be compared and using a multifactorial ANOVA with group (ChR2 vs eYFP) as the between-subjects factor and trial, day, frequency, intracerebral infusion, wheel, or phase of testing as the withinsubject factor, in the case where more than two variables were to be compared. For significant overall interactions, further analyses of partial interactions were performed. Post hoc analyses were performed using the Newman-Keuls test when the initial $p$ value was significant. A result was considered significant if $p<0.05$. All data were analyzed using Statistica software (Statsoft).

\section{Results}

Viral infusion, optic fiber, and cannula placements

Histological examination localized the viral injection site to the perifornical lateral hypothalamic area at the anterior-posterior level of the ventromedial nucleus (Fig. $1 B, C, F, G$ ). The axons from infected neurons projected to the region of the dopamine cell bodies in the VTA (Fig. 1D,E). The optic probes and guide cannula terminated just dorsal to or within (respectively) the ventral tegmental area (Fig. $1 H, I)$.

\section{Feeding studies}

Photostimulation at 5 and 10 but not 2.5 or $20 \mathrm{~Hz}$ induced reliable feeding of dry laboratory chow in ChR2 but not eYFP mice 

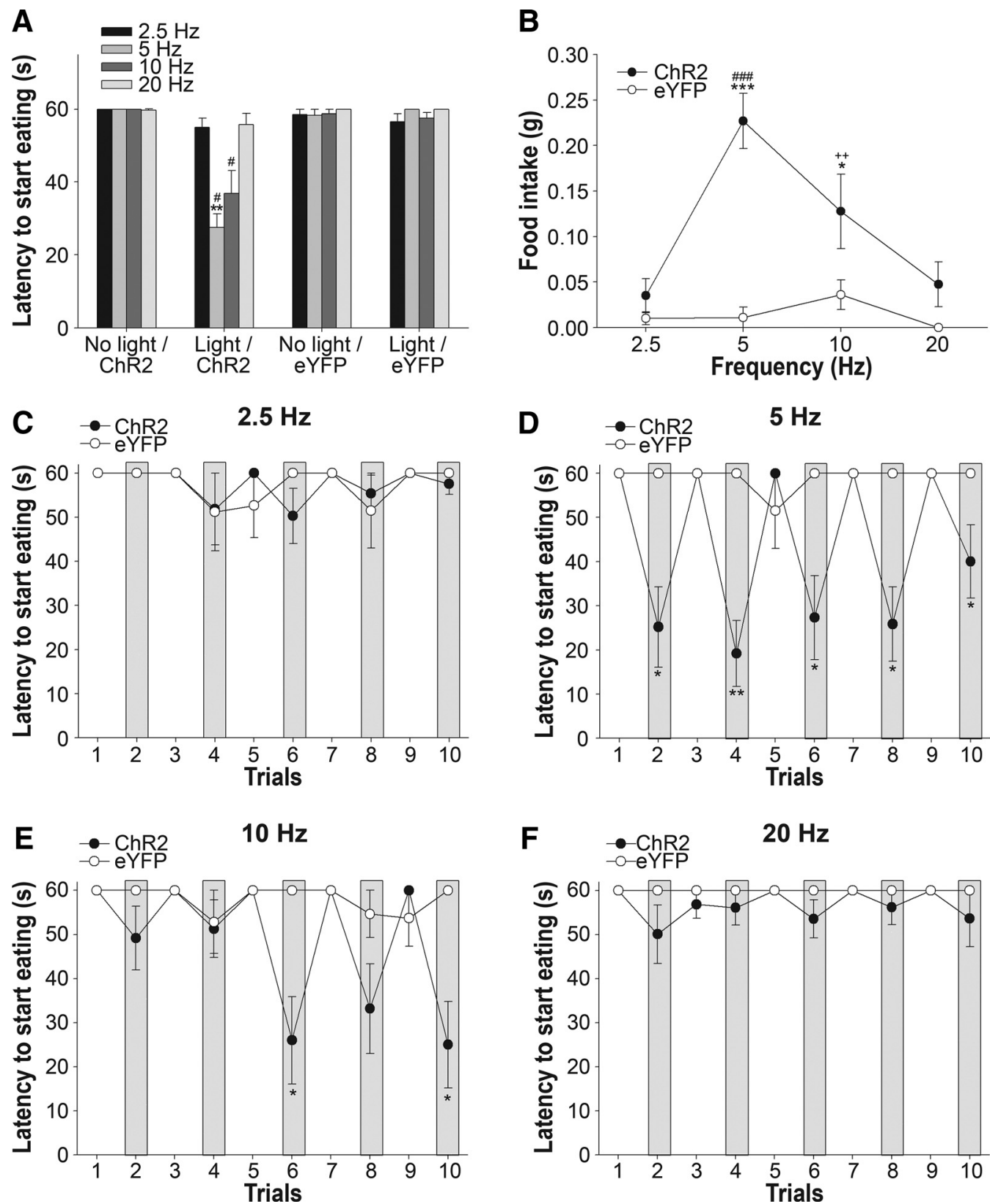

Figure 2. Feeding is promoted by VTA photoactivation of GABAergic lateral hypothalamic terminals. A, Latency to eat in response to onset of optical stimulation at four stimulation frequencies. The five $5 \mathrm{~min}$ trials with and without light were averaged together for both $\operatorname{eYFP}(n=7)$ and ChR2 mice $(n=6)$. ChR2 mice showed a shorter latency to start eating when frequencies of $5 \mathrm{~Hz}$ and, to a lesser extent, $10 \mathrm{~Hz}$, were used. ${ }^{*} p<0.05$ compared with the no-light period; ${ }^{* *} p<0.01$ compared with the light period of eYFP mice. The photostimulation had no effect on eYFP mice at any of the frequencies tested. $\boldsymbol{B}$, Photostimulation of GABAergic LH-to-VTA projections induced feeding at low frequencies in ChR2 mice and had no effect on eYFP mice. Asterisks indicate significant differences between eYFP and ChR2 mice tested with the same frequency. ${ }^{*} p<0.05 ;{ }^{* * *} p<0.001$. Hash marks indicate significant differences between the amount eaten by ChR2 mice stimulated at $5 \mathrm{~Hz}$ against all the other frequencies ( ${ }^{\# \#} p<0.001$ ) and plus signs indicate significant differences between the amount eaten by $\mathrm{ChR2}$ mice stimulated at $10 \mathrm{~Hz}$ against 2.5 and $20 \mathrm{~Hz}\left({ }^{++} p<\right.$ 0.01). C, VTA photostimulation of GABAergic LH terminals using a frequency of $2.5 \mathrm{~Hz}$ did not elicit feeding in neither eYFP nor ChR2 mice. D, VTA photostimulation of GABAergic LH terminals using a frequency of $5 \mathrm{~Hz}$ promoted feeding in ChR2 mice, and the effect was time locked to light stimulation (gray blocks). Asterisks indicate a significant difference between eYFP and ChR2 mice. ${ }^{*} p<$ $0.05 ;{ }^{* *} p<0.01$. E, VTA photostimulation of GABAergic LH terminals using a frequency of $10 \mathrm{~Hz}$ less efficiently promoted feeding in ChR2 mice. Asterisks indicate a significant difference between eYFP and ChR2 mice. ${ }^{*} p<0.05$. F, VTA photostimulation of GABAergic LH terminals using a frequency of $20 \mathrm{~Hz}$ did not elicit statistically reliable feeding in our 1 min trials. However, reliable feeding can be demonstrated in longer tests with this frequency (Jennings et al., 2015; Nieh et al., 2015). Thus, Figure 2 shows the relative but not the absolute effectiveness of stimulation at the parameters tested.

(Fig. 2A,C,D-F). The maximal eating responses were seen after 5 $\mathrm{Hz}$ stimulation (Fig. $2 B$; significant main effects of group, $F_{(1,11)}$ $=14.14, p<0.01$; frequency, $F_{(3,33)}=13.36, p<0.001$; group by frequency interaction, $\left.F_{(3,33)}=10.91, p<0.001\right)$. The food intake elicited by $10 \mathrm{~Hz}$ stimulation was significantly less than that seen at $5 \mathrm{~Hz}(p<0.01)$; statistically reliable food intake was not seen with 2.5 or $20 \mathrm{~Hz}$ stimulation in our short (1 min) test trials.
When ChR2 mice were presented with pieces of cardboard along with regular laboratory chow and tested with $5 \mathrm{~Hz}$ photostimulation, ChR2 mice sometimes picked up a piece of cardboard during the stimulation period (Fig. $3 A, D$ ). When they did so, they carried rather than gnawed the cardboard, usually putting it down and picking up food. Latencies to pick up and carry cardboard were significantly longer than latencies to pick up and 

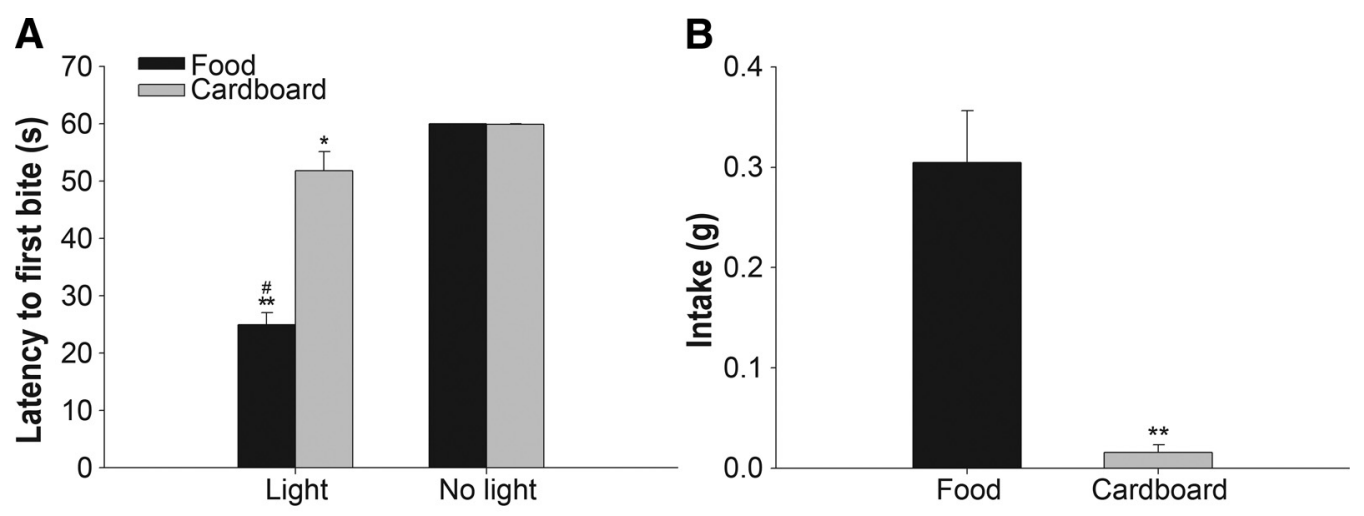

C

Food

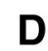

Cardboard

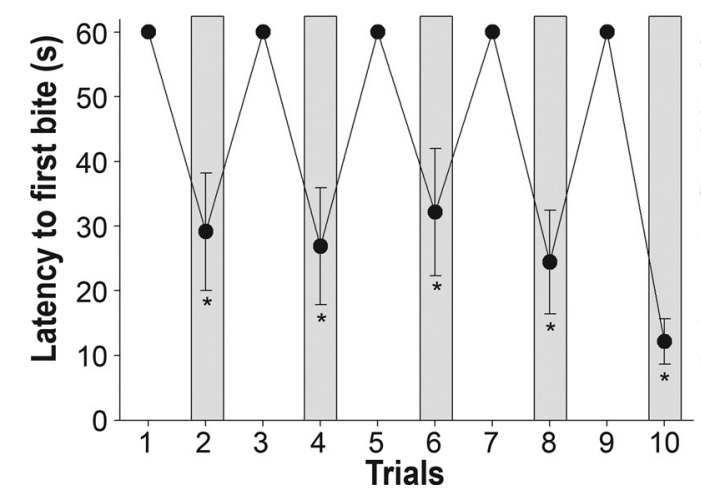

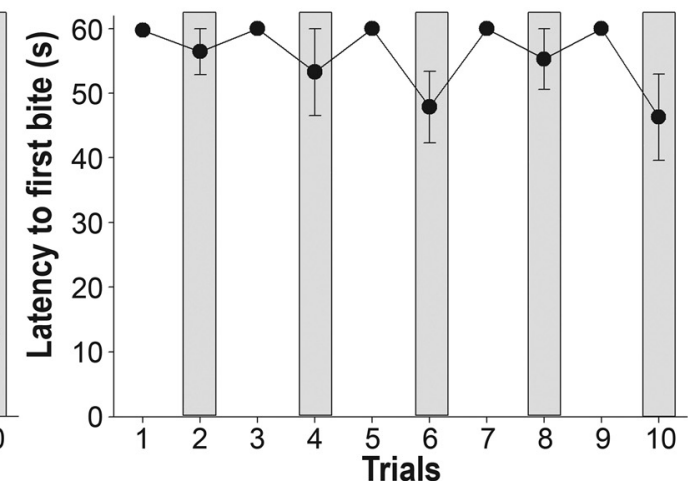

Figure 3. Feeding behavior elicited by VTA photostimulation of GABAergic LH terminals using a stimulation frequency of $5 \mathrm{~Hz}$ is goal directed and not the result of maladaptive motor sequences. $A$, When food pellets and cardboard were presented together to ChR2 mice $(n=6)$, the VTA photostimulation of GABAergic LH terminals induced a shorter latency to bite food than to bite cardboard. ${ }^{\#} p<0.05 ;{ }^{* *} p<0.01$. Asterisks indicate significant differences between the light and the no light periods. ${ }^{*} p<0.05$. $\boldsymbol{B}$, Intake of food was significantly greater than shredding of cardboard $\left({ }^{* *} p<0.01\right)$; the amount of cardboard shredded did not differ significantly from zero $(p=0.07)$. C, VTA photostimulation of GABAergic LH terminals using a frequency of $5 \mathrm{~Hz}$ elicited feeding despite the presence of cardboard pieces in the same behavioral trial. Asterisks indicate a significant difference in the latencies to the first bite for food and cardboard $\left.{ }^{*} p<0.05\right)$. D, Latency to pick up cardboard did not differ significantly from $60 \mathrm{~s}$.

eat food $\left(\chi_{3}^{2}=19.14, p<0.001\right.$; Fig. $\left.3 A\right)$. Animals presented with food alone ate with the same latencies as animals presented with food and cardboard (Figs. 2D, 3C). Finally, the total food intake was not different from that observed when food was presented alone $\left(t_{(6)}=-2.14, p=0.08\right.$; compare Figs. $\left.2 B, 3 B\right)$.

VTA infusions of the GABA antagonists saclofen and picrotoxin significantly decreased amounts eaten (Fig. $4 A ; t_{(6)}=3.76$, $p<0.01$ ) and increased the latency to start eating (Fig. $4 B ; \chi_{3}^{2}=$ $17.46, p<0.001)$ in ChR2 mice given maximally effective $(5 \mathrm{~Hz})$ photostimulation. The decrease on feeding behavior seen with the GABA antagonists was not accompanied by a decrease in distance traveled (Fig. $4 C$; $t_{(6)}=-1.10, p=0.31$, n.s.) or average speed of locomotion (Fig. $4 D ; t_{(6)}=-1.04, p=0.34$, n.s.).

\section{Optical self-stimulation studies}

ChR2 but not eYFP mice readily learned to turn the response wheels for $2 \mathrm{~s}$ trains of VTA photostimulation (Fig. 5). ChR2 mice selectively turned the active wheel to get VTA photostimulation at $20 \mathrm{~Hz}\left(8 \mathrm{~mW}, 10 \mathrm{~ms}\right.$; Fig. $5 A$; day, $F_{(9,54)}=11.77, p<0.001$; wheel, $F_{(1,6)}=7.70, p<0.05$; day by wheel interaction, $F_{(9,54)}=$ 263.07, $p<0.001$ ); eYFP mice did not do so (day, $F_{(9,45)}=1.39$, $p=0.22$; wheel, $F_{(1,5)}=0.58, p=0.48$; day by wheel interaction, $F_{(9,45)}=1.57, p=0.15$, all n.s.). ChR2 mice learned to distinguish between active and inactive wheels within the first $10 \mathrm{~min}$ of testing (minute by wheel interaction, $F_{(14,84)}=8.78, p<0.001$; Newman-Keuls post hoc test at 10 min point, $p<0.01$ ). These animals rarely turned the inactive wheel and quickly changed wheels when the previously active wheel was made inactive and the previously inactive wheel made active (minute by wheel interaction, $F_{(14,84)}=31.10, p<0.001$; Newman-Keuls post hoc test at 7 min point, $p<0.01)$. The number of earned stimulation trains (Fig. $5 B)$ and the efficiency of wheel turning $\left(F_{(8,48)}=9.81\right.$, $p<0.001$; Fig. $5 C$ ) increased progressively over the $10 \mathrm{~d}$ of training.

The rewarding effect of photostimulation was frequency dependent (Fig. 5D). The highest rates of responding were for 40 and $80 \mathrm{~Hz}$ stimulation, depending on pulse width; $80 \mathrm{~Hz}$ was most effective with short pulse widths ( 1.25 and $2.5 \mathrm{~ms}$ ) and 40 $\mathrm{Hz}$ was most effective with long pulse widths (5 and $10 \mathrm{~ms}$ ). ANOVA showed significant differences in the operant performance of each parameter and the interaction between the two (pulse duration, $F_{(3,15)}=15.82, p<0.001$; pulse frequency, $F_{(7,35)}$ $=61, p<0.001$; duration by frequency interaction, $F_{(21,105)}=$ $2.16, p<0.01)$. There were no significant differences in the effectiveness of $5 \mathrm{~ms}$ pulses [the pulse durations used in the Nieh et al. (2015) andJennings et al., 2015 studies], and 10 ms pulses (used in the other experiments in the present study).

Numbers of stimulation-induced wheel turns and stimulations earned were attenuated by VTA microinjections of the mixture of the GABA antagonists saclofen $(500 \mu \mathrm{M})$ and picrotoxin $(100 \mu \mathrm{M}$; Fig. $6 A, B)$. This was reflected in a main effect of treatment $\left(F_{(1,6)}=23.55, p<0.01\right)$, a main effect of wheel $\left(F_{(1,6)}=\right.$ 

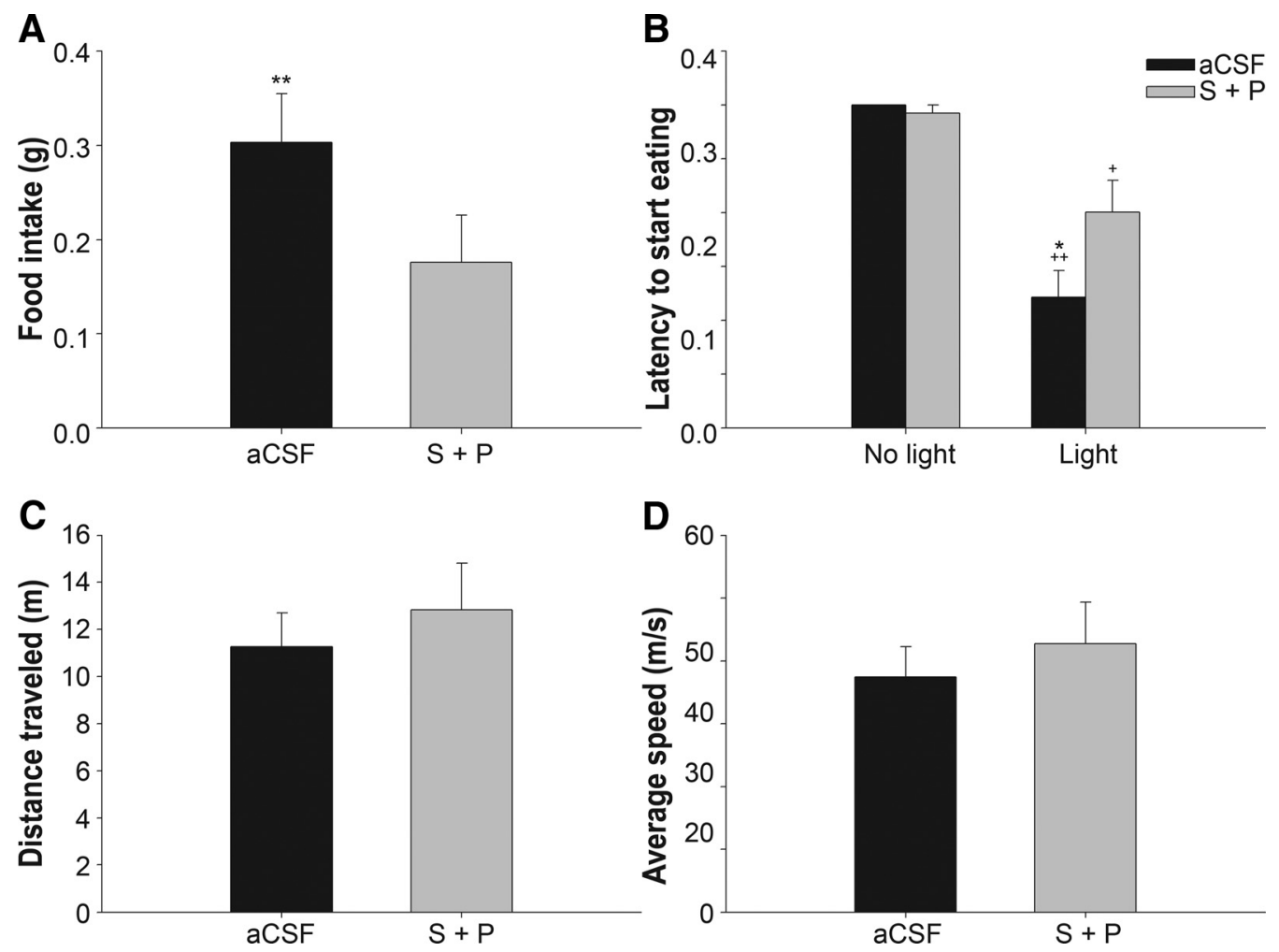

Figure 4. Blockade of $G_{A B A}$ and $G A B A_{B}$ receptors by a mix of saclofen and picrotoxin $(S+P ; 500 \mu \mathrm{m}$ and $100 \mu \mathrm{m}$, respectively) decreased the food intake and increased the latency to start eating induced by VTA photostimulation of GABAergic $\mathrm{LH}$ terminals when these are stimulated at $5 \mathrm{~Hz}(10 \mathrm{~ms}, 8 \mathrm{~mW})$. The observed effects were not due to motor impairment caused by the microinfusion of the antagonists. A, ChR2 mice $(n=8)$ received an intra-VTA infusion $(0.2 \mu l)$ of ACSF or a mix of saclofen plus picrotoxin with an interval of $72 \mathrm{~h}$ between infusions. Administration of the GABA antagonists significantly decreased food intake. The asterisks indicate a significant difference between treatments. ${ }^{* *} p<0.01$. $\boldsymbol{B}$, The latency to start eating was significantly increased by the administration of the GABA antagonists. The asterisk indicates a significant difference between treatments during the photostimulation period. ${ }^{*} p<0.05$. Plus signs indicate significant differences between the light and the no light periods of testing for each condition. ${ }^{+} p<0.05 ;{ }^{++} p<0.01$. C, The total distance traveled by ChR2 mice during the 10 min experiment was not modified by the administration of the antagonists. $\boldsymbol{D}$, The average speed of ChR2 mice during the 10 min experiment was not modified by the administration of the antagonists.

32.83, $p<0.01)$, and a treatment by wheel interaction $\left(F_{(1,6)}=\right.$ 28.82, $p<0.01)$. The ChR2 mice no longer discriminated between the active and inactive wheels following the GABA antagonist treatment (Fig. $6 A ; p=0.49$, n.s.).

\section{Preferred duration and place conditioning}

ChR2 but not eYFP mice quickly learned to shuttle between chambers for 40 (Fig. 7A), but did not reliably do so for $5 \mathrm{~Hz}$ stimulation (Fig. $7 B$ ). This was reflected in a group by chamber interaction $\left(F_{(2,18)}=6.97, p<0.01\right)$ with the ChR2 animals spending over $90 \%$ of their time in the stimulation-associated chamber from the first day of testing when the stimulation frequency was $40 \mathrm{~Hz}$ (Fig. 7A; $p<0.001$ ). This was an instrumental task where the animals controlled the duration of continuous stimulation trains; the ChR2 animals tested with $40 \mathrm{~Hz}$ stimulation spent more time per entry in the reinforced chamber than the animals tested with $5 \mathrm{~Hz}$ stimulation (Fig. $7 \mathrm{C}$ ).

In subsequent preference testing in the absence of any stimulation, neither the animals trained with $5 \mathrm{~Hz}$ stimulation nor the animals trained with $40 \mathrm{~Hz}$ stimulation showed a preference for the compartment in which they had received stimulation over the compartments (end and connecting) where they had never received stimulation.

\section{Discussion}

The present study confirms that reward and motivation to eat can each be induced by activation of GABAergic fibers to the VTA from cells of origin in the lateral hypothalamic area and reveals that the two effects are differentially sensitive to high- and lowfrequency stimulation. While this suggests that different populations of GABA fibers mediate the two effects, it seems unlikely that subpopulations of GABAergic fibers with the same origin and projection (present study), the same refractory periods (Gratton and Wise, 1988b), and the same alignment along the medial forebrain bundle (Gratton and Wise, 1988a) would have such different frequency responses to the stimulation itself. It seems more likely that high and low frequencies activate the same GABAergic fibers but that differences in transmitter release from those fibers differentially affect synaptic targets in the VTA. One possibility is that reward but not feeding depends on a coreleased peptide; peptide cotransmitters tend to be released by higherfrequency stimulation than are needed for release of amino acid transmitters (Arrigoni and Saper, 2014), and peptide corelease appears to be involved in at least some cases of reward function (You et al., 1998). Several hypothalamic neuropeptides have been shown to affect feeding behavior (Woods et al., 1998; Meister, 2007; Benarroch, 2010; Berthoud and Münzberg, 2011). Of these, however, neurotensin, hypocretin/orexin, and melanin concentrating hormone $(\mathrm{MCH})$ appear not to be involved. Hypocretin/ orexin and $\mathrm{MCH}$ are not colocalized with GABA in LH neurons implicated in stimulation-induced feeding (Jennings et al., 2015), and neurotensin, besides being anorexigenic (Levine et al., 1983; Cador et al., 1986), is more concentrated in more rostral regions of the hypothalamus (Geisler and Zahm, 2006), where it appears to be associated with glutamatergic rather than GABAergic re- 

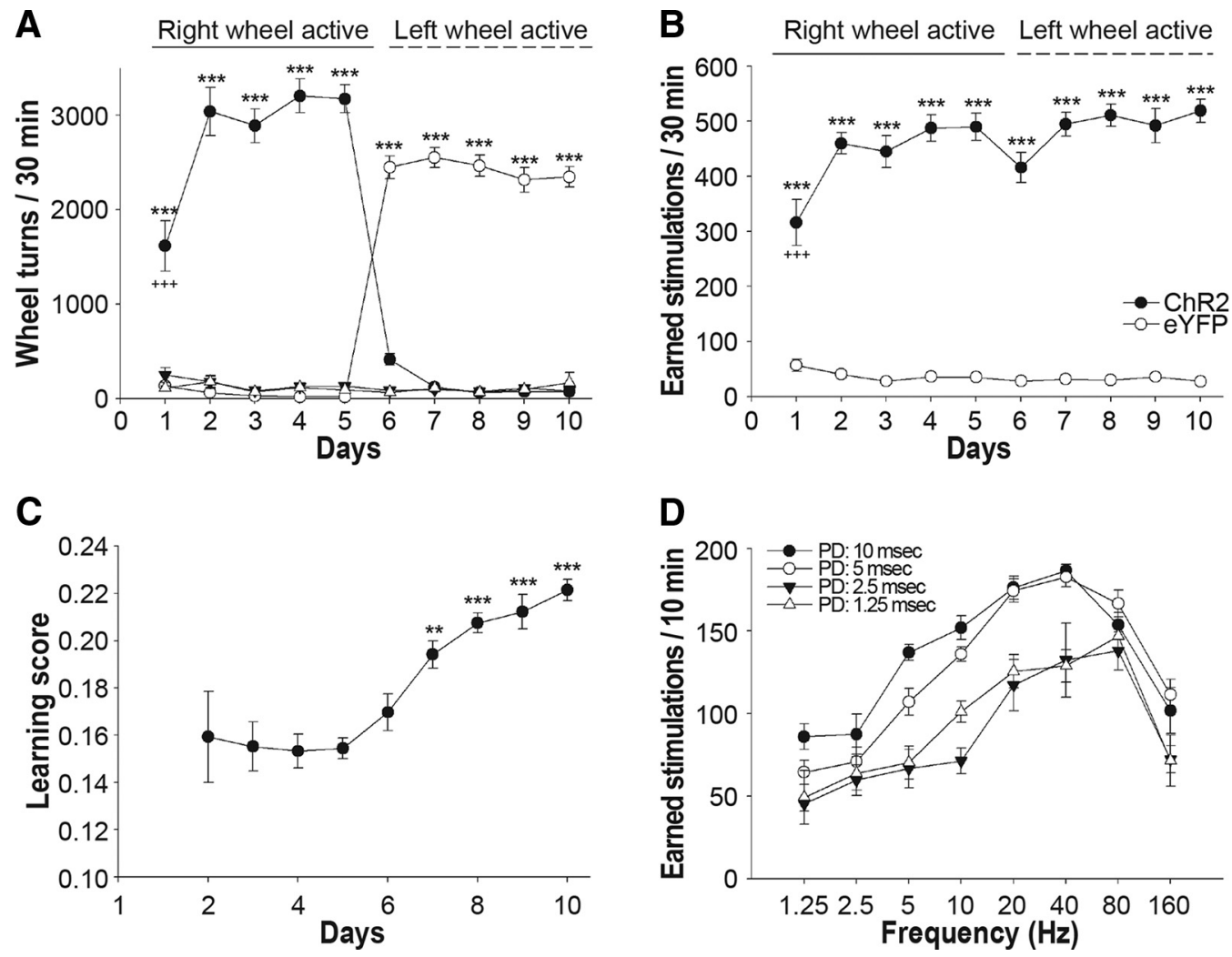

Figure 5. Instrumental behavior is promoted by VTA photoactivation of GABAergic lateral hypothalamic terminals. $A$, ChR2 mice $(n=6)$ turn the active wheel to receive VTA photostimulation of GABAergic LH terminals at $20 \mathrm{HZ}$ significantly more than eYFP mice $(n=7)$, starting from the first day of training. During the first $5 \mathrm{~d}$ of training, turning the right wheel led to the delivery of light stimulation (filled circles). During days 6 to 10, we exchanged the contingencies, so turning the left wheel led to the delivery of light stimulation (unfilled circles). Triangles indicate data for the eYFP animals. Asterisks indicate a significant difference between eYFP and ChR2 mice on a given day. ${ }^{* * *} p<0.001$. Plus signs indicate a significant difference between the number of wheel turns on the first day and the number of wheel turns on the other days for ChR2 mice. ${ }^{+++} p<0.001$. The operant performance in days 6 to 10 is significantly lower than that observed on days 2 to 5 ( $p<$ 0.001). $\boldsymbol{B}$, Earned stimulations during the instrumental training at $20 \mathrm{~Hz}$, when the active wheel was the right wheel (days $1-5$, filled circles) and when the active wheel was the left wheel (days $6-10$, filled circles). Asterisks indicate a significant difference between eYFP and ChR2 mice on any given day. ${ }^{* * *} p<0.001$. Plus signs indicate a significant difference between the number of earned stimulations on the first day and the number of earned stimulations on the other days for ChR2 mice. ${ }^{+++} p<0.001$. Notice that, despite the reversal in the contingencies of wheels, the number of earned stimulations remains considerably stable. C, Learning score resulting from the division of the number of earned stimulations at $20 \mathrm{~Hz}$ by the total number of wheel turns during days 2 to 10 for ChR2 mice $(n=6)$. Mice adjusted their behavior, maximizing the number of wheel turns per earned light stimulation, even with the confound of reversal training, and became significantly more efficient with experience. Asterisks indicate significant differences with days 2 to $6 .{ }^{* *} p<0.01 ;{ }^{* * *} p<0.001$. D, Parametric study of the frequency and pulse duration of the VTA photostimulation of GABAergic LH terminals in ChR2 mice $(n=6)$. A unique pulse duration (PD) was tested each day. On a given day, half of the mice experienced the set of eight frequencies in an ascending order and half in a descending order. Each frequency was tested for $10 \mathrm{~min}$. The best operant performances were evident at frequencies of $20-40 \mathrm{~Hz}$ and at pulse durations of $5-10 \mathrm{~ms}$. The statistical analyses performed and the results are described in the Materials and Methods.
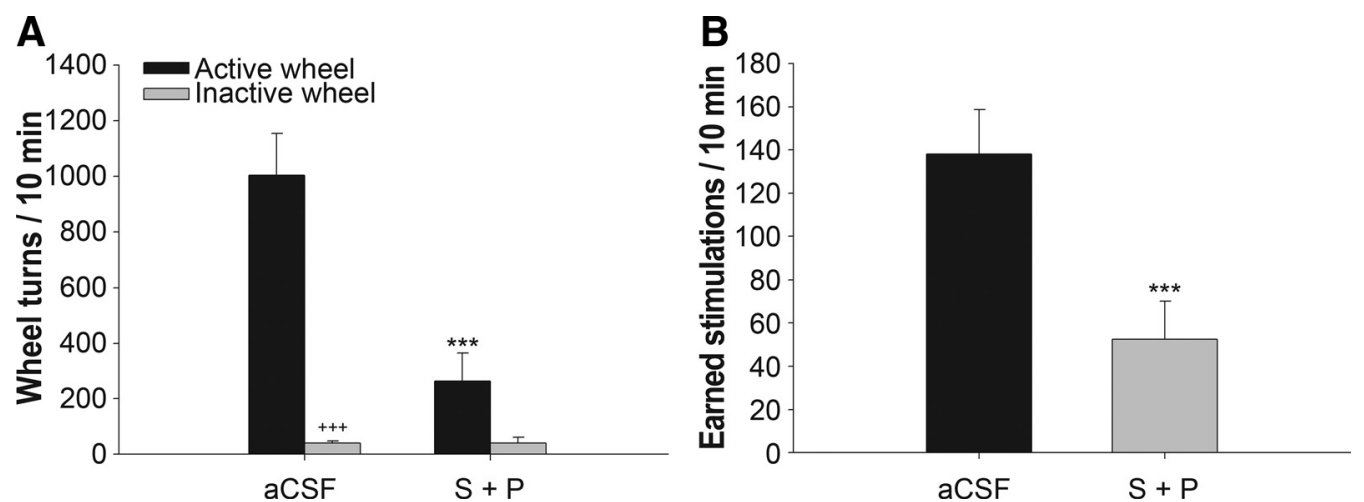

Figure 6. Blockade of $\mathrm{GABA}_{\mathrm{A}}$ and $\mathrm{GABA}_{B}$ receptors by a mix of saclofen and picrotoxin ( $\mathrm{S}+\mathrm{P} ; 500 \mu \mathrm{m}$ and $100 \mu \mathrm{m}$, respectively) decreased responding for VTA photostimulation of $\mathrm{GABAergic}$ LH terminals at $40 \mathrm{~Hz}$. ChR2 mice $(n=8)$ received an intra-VTA infusion $(0.2 \mu \mathrm{l})$ of ACSF or a mix of saclofen plus picrotoxin with an interval of $72 \mathrm{~h}$ between infusions. $A$, Administration of the $G A B A$ antagonists significantly decreased the number of wheel turns on the active, but not the inactive, wheel. The discrimination between wheels was no longer evident after $G_{A B A_{A}}$ and $G A B A_{B}$ receptor blockade. The asterisks indicate a significant difference between treatments on the number of active wheel turns. ${ }^{* *} p<0.001$. The plus signs indicate a significant difference between the number of active and inactive wheel turns for a given treatment. ${ }^{++} p<0.001$. B, Earned light stimulations during VTA photoactivation of the GABAergic LH terminals were significantly decreased by the administration of the GABA antagonists mix. ${ }^{* *} p<0.001$. 

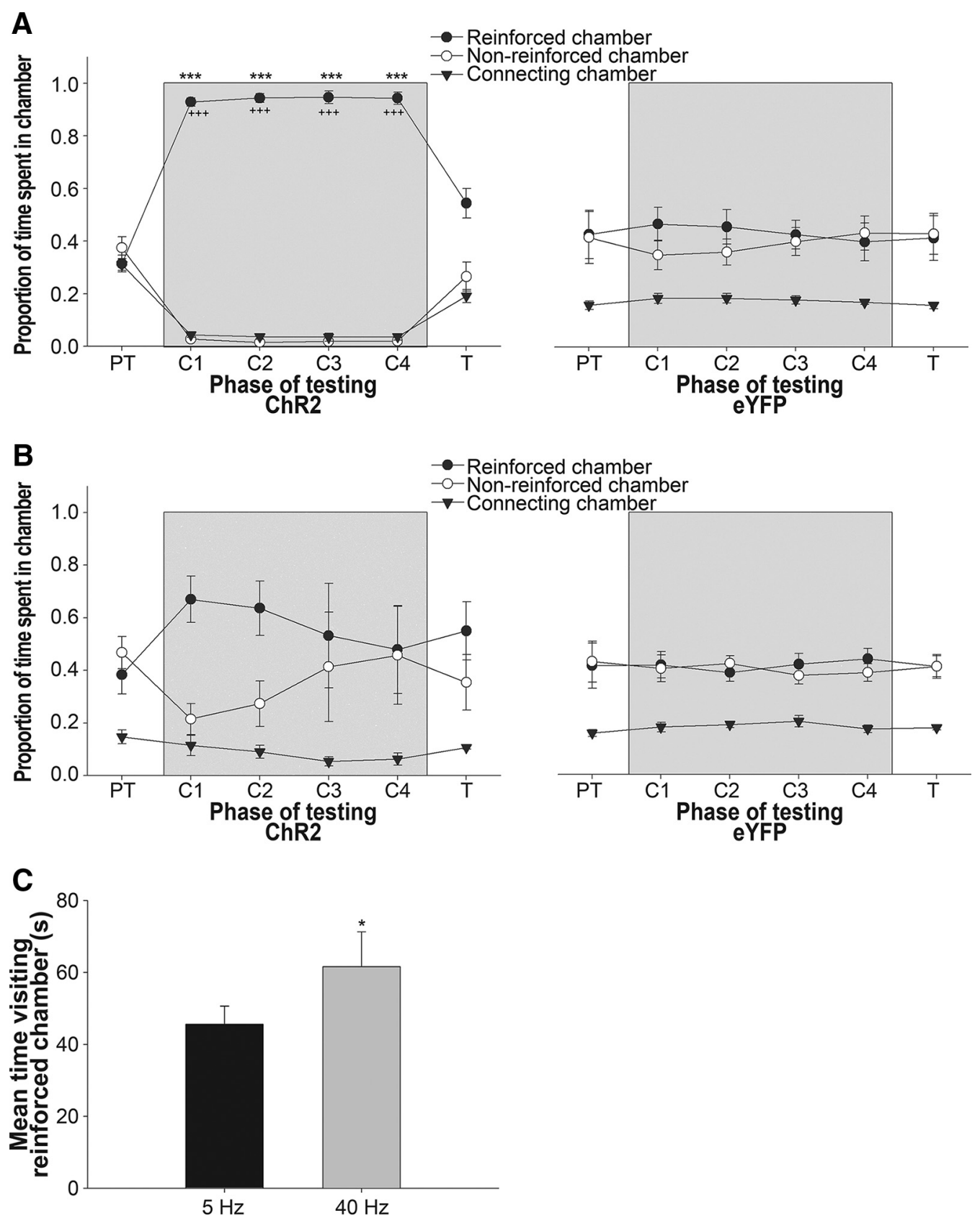

Figure 7. Time spent in each of the three test chambers on consecutive days — before stimulation [pretest day (PT)], when stimulation was available in one of the chambers [conditioning days 1-4 (C1-C4); gray zone], or when stimulation was no longer available after conditioning trials [test day (T)] —in high-frequency ( $40 \mathrm{~Hz})$ and low-frequency $(5 \mathrm{~Hz})$ stimulation conditions. $A$, ChR2 mice ( $n=6$, left) and eYFP mice $(n=7$, right) received continuous light stimulation at a frequency of $40 \mathrm{~Hz}$ when entering the reinforced chamber. Mice were able to stop the stimulation by passing to the connecting or the nonreinforced chamber. Gray squares indicate the days in which the light stimulation was available. ChR2 mice showed a significant preference for the reinforced chamber during the conditioning days (when the light was available). Asterisks indicate significant differences between ChR2 and eYFP mice on a given testing phase. ${ }^{* * *} p<0.001$. Plus signs indicate significant differences between the time spent in the reinforced and the nonreinforced chambers for ChR2 mice on a given testing phase. ${ }^{+++} p<0.001 . B$, ChR2 mice $(n=5$, left) and eYFP mice ( $n=7$, right) received continuous light stimulation at a frequency of $5 \mathrm{~Hz}$ when entering the reinforced chamber. Mice were able to stop the stimulation by passing to the connecting or the nonreinforced chamber. Gray squares indicate the days in which the light stimulation was available. Neither ChR2 nor eYFP mice showed statistically reliable preference for the reinforced chamber during any phase of training, though the data from days $\mathrm{C} 1$ and $\mathrm{C} 2$ suggest some degree of preference for $5 \mathrm{~Hz}$ stimulation in the ChR2 group, consistent with the wheel-turning behavior for $5 \mathrm{~Hz}$ stimulation. C, Mean visit time to the reinforced chamber as a function of stimulation frequency. Mice given stimulation at $5 \mathrm{~Hz}$ made significantly shorter visits than when given $40 \mathrm{~Hz}$ stimulation $\left(t_{(6)}=-2.36\right) .{ }^{*} p=0.05$.

ward signaling in the VTA (Kempadoo et al., 2013). The study of other candidates that project to the VTA, such as galanincontaining neurons and a subset of GABAergic LH neurons that express leptin receptors and modulate feeding (Melander et al., 1986; Meister and Hökfelt, 1988; Woods et al., 1998; Leinninger et al., 2009), are of obvious interest. Regardless of the possibility of a peptidergic cotransmission along with GABA, the fact that
GABA antagonists decreased feeding and reward when applied in the VTA emphasizes the modulatory role of this classical neurotransmitter in both responses.

In the present study, the stimulation was rewarding even in uninterrupted trains of pulses lasting tens of seconds. In the case of electrical stimulation of the same brain region, prolonged stimulation tends to become aversive after several seconds, and 
rats will not only work to initiate LH stimulation, but will subsequently work to terminate it (only to initiate it again) (Bower and Miller, 1958). One hypothesis is that the effects of electrical stimulation are initially rewarding but become aversive and drive-like with prolonged duration (Ball, 1970). This hypothesis does not explain our optogenetic findings. We saw no signs that our optogenetic stimulation became aversive around the time the animals started eating; when the animals controlled the duration of stimulation in the absence of food, their continued preference for stimulation lasted considerably longer (mean, $45.6 \mathrm{~s}$; Fig. $7 C)$ than their latencies to initiate eating when food was present $(\sim 30 \mathrm{~s}$; Fig. $2 D)$.

An interesting contrast to our finding is seen with optogenetic activation of agouti-related protein-expressing neurons of the arcuate nucleus. This stimulation induces feeding but becomes aversive over the course of several days of repeated testing (Betley et al. 2015). It is tempting to consider the possibility that this system, which is sensitive to the hormonal signals of energy balance (van den Top et al., 2004), is more involved in regulatory feeding and that the medial forebrain bundle system is more involved in eating in the absence of need.

In a previous study of feeding induced by optogenetic activation of GABAergic LH $\rightarrow$ VTA, Nieh et al. (2015) reported aberrant behaviors that were not seen in our study. These included circling and vacuous tongue movements (their Video S3) and backward propulsion (their Video S4). The circling probably reflects the laterality of their optic probe, which was positioned over the substantia nigra, $0.7 \mathrm{~mm}$ lateral to our placement. The backward stepping is a clear sign of aversion (Schneirla, 1959) and a response that was never seen in our study. This effect may have been due to stimulation of a somewhat more rostral set of GABA neurons than the one stimulated in our study. The viral injections in the study by Nieh et al. (2015) were about $1 \mathrm{~mm}$ rostral to ours, at the level of the decussation of the optic chiasm; our injections and those of Jennings et al., (2015), who also reported no aberrant behavioral signs, were at the anterior-posterior level of the ventromedial nucleus, the region where electrical stimulation induces eating (Hoebel and Teitelbaum, 1962; Margules and Olds, 1962; Wise, 1971).

Nieh et al. (2015) also reported licking and gnawing in their stimulated animals. We also saw mouth movements in response to $20 \mathrm{~Hz}$ stimulation at times when our animals did not have food in their mouths. We did not see such movements when stimulating at the lower frequencies that induced eating. The tongue protrusions seen in Nieh et al.'s (2015) S3 video have the appearance of "gapes": the reflexes of oral expulsion (Grill and Norgren, 1978). This may have been due to salivation that can be caused by hypothalamic stimulation, but it was also not seen in our study. We did not see these movements or the gnawing-like mouth movements seen by Nieh et al. (2015) in animals with nothing to chew. We sometimes noticed in vacuo chewing movements with stimulation at $20 \mathrm{~Hz}$, but we did not see chewing of the cardboard pieces our animals sometimes carried before picking up food.

Our findings confirm that activation of a GABAergic projection from lateral hypothalamic cells of origin can induce feeding and reward. The feeding effect is optimal when low $(5 \mathrm{~Hz})$ stimulation frequencies are used; the rewarding effect is optimal with higher frequencies ( 40 or $80 \mathrm{~Hz}$ ) are used. Our working hypothesis at present is that the same GABAergic fibers are involved in both behaviors and that differential effects on downstream targets explain the so-called "drive-reward" paradox.

\section{References}

Anand BK, Brobeck JR (1951) Localization of a "feeding center" in the hypothalamus of the rat. Proc Soc Exp Biol Med 77:323-324. CrossRef Medline

Arrigoni E, Saper CB (2014) What optogenetic stimulation is telling us (and failing to tell us) about fast neurotransmitters and neuromodulators in brain circuits for wake-sleep regulation. Curr Opin Neurobiol 29: 165-171. CrossRef Medline

Ball GG (1970) Hypothalamic self stimulation and feeding: Different time functions. Physiol Behav 5:1343-1346. CrossRef Medline

Benarroch EE (2010) Neural control of feeding behavior: overview and clinical correlations. Neurology 74:1643-1650. CrossRef Medline

Berthoud HR, Münzberg H (2011) The lateral hypothalamus as integrator of metabolic and environmental needs: from electrical self-stimulation to opto-genetics. Physiol Behav 104:29-39. CrossRef Medline

Betley JN, Xu S, Cao ZF, Gong R, Magnus CJ, Yu Y, Sternson SM (2015) Neurons for hunger and thirst transmit a negative-valence teaching signal. Nature 521:180-185. Medline

Bielajew C, Shizgal P (1982) Behaviorally derived measures of conduction velocity in the substrate for rewarding medial forebrain bundle stimulation. Brain Res 237:107-119. CrossRef Medline

Bielajew C, Bushnik T, Konkle AT, Schindler D (2000) The substrate for brain-stimulation reward in the lateral preoptic area. II. Connections to the ventral tegmental area. Brain Res 881:112-120. CrossRef Medline

Bower GH, Miller NE (1958) Rewarding and punishing effects from stimulating the same place in the rat's brain. J Comp Physiol Psychol 51:69-72. Medline

Cador M, Kelley AE, Le Moal M, Stinus L (1986) Ventral tegmental area infusion of substance $\mathrm{P}$, neurotensin and enkephalin: differential effects on feeding behavior. Neuroscience 18:659-669. CrossRef Medline

Ettenberg A, Duvauchelle CL (1988) Haloperidol blocks the conditioned place preferences induced by rewarding brain stimulation. Behav Neurosci 102:687-691. CrossRef Medline

Geisler S, Zahm DS (2006) Neurotensin afferents of the ventral tegmental area in the rat: [1] re-examination of their origins and [2] responses to acute psychostimulant and antipsychotic drug administration. Eur J Neurosci 24:116-134. CrossRef Medline

Gratton A, Wise RA (1988a) Comparisons of connectivity and conduction velocities for medial forebrain bundle fibers subserving stimulationinduced feeding and brain stimulation reward. Brain Res 438:264-270. CrossRef Medline

Gratton A, Wise RA (1988b) Comparisons of refractory periods for medial forebrain bundle fibers subserving stimulation-induced feeding and brain stimulation reward: a psychophysical study. Brain Res 438:256263. CrossRef Medline

Grill HJ, Norgren R (1978) The taste reactivitiy test. I. Mimetic responses to gustatory stimuli in neurologically intact rats. Brain Res 143:263-279. CrossRef Medline

Hoebel BG (1969) Feeding and self-stimulation. Ann N Y Acad Sci 157: 758-778. CrossRef

Hoebel BG, Teitelbaum P (1962) Hypothalamic control of feeding and selfstimulation. Science 135:375-377. CrossRef Medline

Jennings JH, Ung RL, Resendez SL, Stamatakis AM, Taylor JG, Huang J, Veleta K, Kantak PA, Aita M, Shilling-Scrivo K, Ramakrishnan C, Deisseroth K, Otte S, Stuber GD (2015) Visualizing hypothalamic network dynamics for appetitive and consummatory behaviors. Cell 160:516-527. CrossRef Medline

Kempadoo KA, Tourino C, Cho SL, Magnani F, Leinninger GM, Stuber GD, Zhang F, Myers MG, Deisseroth K, de Lecea L, Bonci A (2013) Hypothalamic neurotensin projections promote reward by enhancing glutamate transmission in the VTA. J Neurosci 33:7618-7626. CrossRef Medline

Leinninger GM, Jo YH, Leshan RL, Louis GW, Yang H, Barrera JG, Wilson H, Opland DM, Faouzi MA, Gong Y, Jones JC, Rhodes CJ, Chua S Jr, Diano S, Horvath TL, Seeley RJ, Becker JB, Münzberg H, Myers MG Jr (2009) Leptin acts via leptin receptor-expressing lateral hypothalamic neurons to modulate the mesolimbic dopamine system and suppress feeding. Cell Metab 10:89-98. CrossRef Medline

Levine AS, Kneip J, Grace M, Morley JE (1983) Effect of centrally administered neurotensin on multiple feeding paradigms. Pharmacol Biochem Behav 18:19-23. Medline 
Margules DL, Olds J (1962) Identical "feeding" and "rewarding" systems in the lateral hypothalamus of rats. Science 135:374-375. CrossRef Medline

Meister B (2007) Neurotransmitters in key neurons of the hypothalamus that regulate feeding behavior and body weight. Physiol Behav 92: 263-271. CrossRef Medline

Meister B, Hökfelt T (1988) Peptide and transmitter-containing neurons in the mediobasal hypothalamus and their relation to GABAergic systems: possible roles in control of prolactin and growth hormone secretion. Synapse 2:585-605. CrossRef Medline

Melander T, Hökfelt T, Rökaeus A, Cuello AC, Oertel WH, Verhofstad A, Goldstein M (1986) Coexistence of galanin-like immunoreactivity with catecholamines, 5-hydroxytryptamine, GABA and neuropeptides in the rat CNS. J Neurosci 6:3640-3654. Medline

National Research Council (2011) Guide for the care and use of laboratory animals. Washington, DC: National Academies.

Nieh EH, Matthews GA, Allsop SA, Presbrey KN, Leppla CA, Wichmann R, Neve R, Wildes CP, Tye KM (2015) Decoding neural circuits that control compulsive sucrose seeking. Cell 160:528-541. CrossRef Medline

Olds J (1956) A preliminary mapping of electrical reinforcing effects in the rat brain. J of Comparative and Physiological Psychology 49:281-285. CrossRef

Qi J, Zhang S, Wang HL, Wang H, de Jesus Aceves Buendia J, Hoffman AF, Lupica CR, Seal RP, Morales M (2014) A glutamatergic reward input from the dorsal raphe to ventral tegmental area dopamine neurons. Nature communications 5:5390. CrossRef Medline

Ranck JB Jr (1975) Which elements are excited in electrical stimulation of mammalian central nervous system: a review. Brain Res 98:417-440. CrossRef Medline

Saper CB, Chou TC, Elmquist JK (2002) The need to feed: homeostatic and hedonic control of eating. Neuron 36:199-211. CrossRef Medline
Schneirla TC (1959) An evolutionary and developmental theory of biphasic processes underlying approach and withdrawal. In: Nebraska Symposium on Motivation (Jones MR, ed), pp 1-42. Lincoln, NE: University of Nebraska

Shizgal P, Bielajew C, Corbett D, Skelton R, Yeomans J (1980) Behavioral methods for inferring anatomical linkage between rewarding brain stimulation sites. J Comp Physiol Psychol 94:227-237. CrossRef Medline

Stricker EM, Zigmond MJ (1974) Effects on homeostasis of intraventricular injections of 6-hydroxydopamine in rats. J Comp Physiol Psychol 86: 973-994. CrossRef Medline

Ungerstedt U (1971) Adipsia and aphagia after 6-hydroxydopamine induced degeneration of the nigro-striatal dopamine system. Acta Physiol Scand Suppl 367:95-122. Medline

van den Top M, Lee K, Whyment AD, Blanks AM, Spanswick D (2004) Orexigen-sensitive NPY/AgRP pacemaker neurons in the hypothalamic arcuate nucleus. Nat Neurosci 7:493-494. CrossRef Medline

Wise RA (1971) Individual differences in effects of hypothalamic stimulation: the role of stimulation locus. Physiol Behav 6:569-572. CrossRef Medline

Wise RA (1974) Lateral hypothalamic electrical stimulation: does it make animals 'hungry'? Brain Res 67:187-209. CrossRef Medline

Wise RA (2013) Dual roles of dopamine in food and drug seeking: the drivereward paradox. Biol Psychiatry 73:819-826. CrossRef Medline

Woods SC, Seeley RJ, Porte D Jr, Schwartz MW (1998) Signals that regulate food intake and energy homeostasis. Science 280:1378-1383. CrossRef Medline

You ZB, Tzschentke TM, Brodin E, Wise RA (1998) Electrical stimulation of the prefrontal cortex increases cholecystokinin, glutamate, and dopamine release in the nucleus accumbens: an in vivo microdialysis study in freely moving rats. J Neurosci 18:6492-6500. Medline 